\title{
The Respect for Fundamental in EU as an Eligibility for the Candidate Countries: The Albania Case
}

\author{
Valbona Sanxhaktari PhD Cand. \\ Legal Expert, Department of Legislation, \\ Monitoring of Programs and Anticorruption, Office of Prime Minister
}

\author{
Doi:10.5901/mjss.2014.v5n20p2527
}

\begin{abstract}
As it is well known, nowadays, a country aspiring to become a European Union member must ensure respect for human rights and fundamental freedoms, consolidation of democracy and the rule of law, along numerous other economic and legislative criteria. The part of pre-accession standards that have to be achieved, known as political criteria, are the topic of the present paper that aims at assessing the scope of conditionality in the field of human rights promotion and protection in Albania. The first part of the paper offers a chronological overview of the recent EU policies vis-à-vis Albania, particularly regarding human rights requirements the country was askedto fulfill in order for the accession negotiations to be opened. In the second part, the paper deals with actual human rights situation in the country, with special emphasis on several critical registered human rights violations that were registered in previous years.
\end{abstract}

Keywords: European integration, human rights, Albania, candidate country.

\section{Introduction}

Respect for human rights is a value upon which the European Union is founded, and a precondition for an aspirant state to be considered as a candidate for membership. Human rights are universal and indivisible. The European Union therefore actively promotes and defends them both within its borders and in its relations with third countries, living up to its commitments under the EU Fundamental Rights Charter and the Universal Declaration of Human Rights. Article 21 of the Treaty on European Union explicitly states that "the Union's action on the international scene shall be guided by the principles which have inspired its own creation, development and enlargement, and which it seeks to advance in the wider world: democracy, the rule of law, the universality and indivisibility of human rights and fundamental freedoms, respect for human dignity, the principles of equality and solidarity, and respect for the principles of the United Nations Charter and international law."

While expressly required since the Treaty of Amsterdam, respect for human rights has always been a condition for accession to the EU. This condition was bolstered in the context of the Union's enlargement to the east, and has been further entrenched ever since. Three steps could indeed be identified in the strengthening of the human rights conditionality since the 1993 European Council meeting in Copenhagen: First, the introduction of EU monitoring of the Copenhagen political criteria, including human and minority rights protection, through the pre-accession strategy, second, the establishment of a specific chapter in the area of fundamental rights in accession negotiations, and third, the elaboration of a "new approach" in relation to this particular chapter.

The Lisbon Treaty makes two major steps towards advancing human rights protection in the European Union, which will be discussed in turn here. The first, in Article 6(3) of the new Treaty on the European Union (TEU), provides for the possibility of Union accession to the European Convention on Human Rights. This move was one long-advocated by human rights academics, and indeed had been on the table since 1979, when the Commission advocated foraccession to the European Convention on Human Rights. The journey from the Laeken Declaration, through the proposed Constitution for Europe, to the Lisbon (or "Reform") Treaty, is well documented and the history of the Treaty is not one which needs to be versed again here.

The second step is the granting of legal status for the Charter of Fundamental Rights. This was the latest step in the journey of fundamental rights at the EU level, first set in motion in 1969 when the ECJ recognized that fundamental human rights could be classified as "general principles of Community law and therefore were to be protected by the 
Court."'The Charter offundamental Rightsbecame an intrinsic part of the new version of the EU's grounding legal text, the Treaty of Lisbon, signed on 13 December 2007 and has effect as a legal rule?2.

\title{
2. Respecting human rights as a condition of the membership in the EU
}

The modalities of political and economic transition of the Western Balkans differ from the Central and Eastern European (CEE) countries that celebrated their democratization efforts by acceding the European Union (EU) in May 2004. Not only the legacy of violent inter-ethnic conflicts in 1990s, but also authoritarian regimes of that decade have put a stamp of severe human right violator to all of the countries of the region. Even though the (pre)-accession criteria would largely remain the same as for the latest wave of enlargement, political analysts advocate that a state building process that should come first should be followed by implementation of the conditionality principles contained in the Copenhagen Criteria, using these as compliance measures ${ }^{3}$. The assessment of performances of the countries in the region will very likely remain individual, thus diminishing already well-known Croatian fears that the country could be unfairly put into the waiting room for the accession until the other countries of the region meet the conditionality requirements.

Through the so-called "pre-accession strategy", the Union has forged a member-state making policy which has articulated in considerable detail the putative attributes of membership. It has in turn disclosed what the EU stands for, or at least how it wants to be perceived by the outside world. Respect for democracy and fundamental rights is a conditio sine qua non for an aspirant state to be considered as a candidate for membership 4 . Implicit at first, such an eligibility condition was elaborated and codified by the European Council at its Copenhagen meeting in 1993. Thus, according to the so-called "Copenhagen criteria", membership requires that the candidate countrydemonstrates "stability of institutions guaranteeing democracy, the rule of law, human rights and respect for and protection of minorities".

The "Copenhagen criteria" remain the key benchmarks against which the readiness of a third country to accede is assessed. According to the latest formulation of Article 49 TEUwhich sets out the accession procedureprovides that:

\begin{abstract}
"Any European State which respects the values referred to in Article 2 and is committed to promoting them may apply to become a member of the Union. The European Parliament and national Parliaments shall be notified of this application. The applicant State shall address its application to the Council, which shall act unanimously after consulting the Commission and after receiving the assent of the European Parliament, which shall act by an absolute majority of its component members. The conditions of admission and the adjustments to the Treaties on which the Union is founded, which such admission entails, shall be the subject of an agreement between the Member States and the applicant State. This agreement shall be submitted for ratification by all the contracting States in accordance with their respective constitutional requirements. The conditions of eligibility agreed upon by the European Council shall be taken intoaccount."
\end{abstract}

So, paragraph 1: "Any European State which respectsthe values referred to in Article 2 and is committed to promoting them may apply to become a member of the Union" (emphasis added) reflects these eligibility conditions. Though it does not include an explicit mention or a reiteration of the Copenhagen criteria, it also stipulates that "The conditions of eligibility agreed upon by the European Council shall be taken into account", thus alluding to the conditions crafted in Copenhagen.

The European Council also, in codifying and elaborating accession conditions, laid the groundwork for what as become a proactive and meticulous pre-membership policy, namely the 'pre-accession strategy'. The post-Copenhagen approach to enlargement has entailed a pro-active engagement of the EU to steer and monitor the process whereby candidates prepare for membership.Throughout the latter part of the 1990s, new instruments were added to "enhance" the pre-accession strategy. Hence, following the 1997 Luxembourg European Council, the Copenhagen criteria were progressively spelled out in short-, medium- and long-term priorities, compiled in "accession partnerships" (APs) adopted by the EU, and which the candidates would have to meet with a view, and as a condition, to their ultimate admission to the Union. The Commission was also requested to produce detailed evaluations on each candidate's performance in implementing its AP, through the publication of annual progress reports, on the basis of which the (European) Council

'Stauder v. City of Ulm, 1969 ECR 419, 425.

${ }^{2}$ C. Hillion, Enlarging the European Union and deepening its fundamental rights protection, European Policy Analysis 2013, 11, pg 14;A.Petricušic, Pre-Accession Human Rights Record: Assessing the Scope of Conditionality in the Field of Human Rights Promotion and Protection in Croatia, Working Paper, Institute of Austrian, European and Comparative Public Law and Political Sciences, Faculty of Law, University of Graz, pgp,.72-101.

3/nternational Commission on the Balkans, 2005; European Policy Centre, 2005.

${ }^{4}$ M. Cremona (ed), The Enlargement of the European Union, Oxford: Oxford University Press, 2003, pp. 9and 43. 
would determine the pace of accession negotiations. In particular, the pre-accession financial assistance could be reviewed if progress in meeting the Copenhagen criteria was deemed insufficient ${ }^{5}$. The fulfillment of the EU accession conditions, and particularly the respect for fundamental and minority rights, thus became subject to systematic EU monitoring. As this regard the Commission provided an evaluation of the situation. It also formulated recommendations as regards measures that ought to be taken by the candidate to address possible deficiencies, and ultimately to meet the admission conditions ${ }^{6}$. The start of accession negotiations with Croatia and Turkey was a milestone in this respect ${ }^{7}$.

The evolution that is perhaps the most noticeable was the addition of a new chapter 23 on "judiciary and fundamental rights"23 to the list of accession negotiations chapters.24 As a result, respect for human rights is no longer regarded solely as an eligibility condition (i.e. prerequisite for starting accession negotiations) as suggested by Article 49(1) TEU. Fundamental rights are also conceived as an integral part of the EU acquiswhich the candidate has to assimilate and, as such, considered under the third Copenhagen criterion relating to the "candidate's ability to take on the obligations of membership"s. It thus suggests the existence of a normative basis for the EU in the field?.

The articulation of an EU acquison fundamental rights in the context of accession has also been fostered by the new methodology introduced in the negotiations, following the so-called "renewed consensus on enlargement"10.

The new consensus foresees the strengthening of conditionality in accession negotiations with a view to enhancing the credibility of the candidates' preparation for membership ${ }^{11}$.

Based on lessons learned from Croatia's accession process, particularly with respect to the judiciary and fundamental rights, the Commission suggested various adjustments to the negotiations of chapter 23. The general purpose of what has been coined the "new approach", and which has since been endorsed by the European Council, is to invigorate the monitoring of the candidates' absorption of the EU fundamental rights acquisin the context of accession negotiations ${ }^{12}$.

Chapter 23 ,thus, is to be tackled early in the negotiations so as to allow maximum time for the candidate to establish the necessary legislation, institutions and solid track record of implementation before the negotiations are closed, thereby demonstrating that such reforms are solidly embedded in its constitutional fabric, prior to admission.

Some "screening reports", which establish possible gaps between EU law and the candidates' legislation over the whole range of accession chapters, must provide substantial guidance in relation to chapter 23 , including on the tasks to be addressed in the action plans which the candidate state's authorities themselves have to adopt as "opening benchmarks". 13

The new approach includes a system of sanctions, in the form of possible "corrective measures" in case of problems during the negotiations.

It is then up to the Council to decide "by qualified majority on such a proposal, and on the conditions for lifting the measures taken". Based on the "importance of [chapter 23] for the implementation of the acquis across the board", the EU could thus decide to suspend accession negotiations as a whole in case of difficulty in relation to this particular chapter. Progress in the areas of judiciary and fundamental rights has thus become the keystone of the advancement of the entire accession process ${ }^{14}$

Considering that, the new approach typifies the consolidation of the fundamental rights discourse in the context of EU accession. In particular, the elaboration of benchmarking entails further articulation of fundamental rights standards

${ }^{5}$ Council Regulation 622/98 (OJ, 1998, L85/1).

${ }^{6}$ A. Williams, 'Enlargement of the Union and human rights conditionality: a policy of distinction?', European Law Review 25, 2000, p. 601, ${ }^{7}$ C. Hillion, Enlarging the European Union and deepening its fundamental rights protection, European Policy Analysis 2013, 11, pg. 4. ${ }^{8}$ Emphasis added.

${ }^{9} \mathrm{G}$. de Búrca, 'Beyond the Charter: How enlargement has enlarged the human rights policy of the EU' Fordham International Law Journal 27, 2004, p. 679.

${ }_{10}$ Presidency Conclusions, European Council, Brussels, 15 December 2006.

${ }^{11}$ Christophe HillionEnlarging the European Union and deepening its fundamental rights protection, European Policy Analysis 2013:11 . Page 1-4.

${ }^{12}$ Communication from the Commission to the European Parliament and the Council, Enlargement Strategy and Main Challenges 20112012, $\operatorname{COM(2011)~} 666$ final, 12.10.2011, p. 5.

${ }^{13} \mathrm{General}$ EU position - ministerial meeting opening the Intergovernmental Conference on the Accession of Montenegro to the European Union (AD 23/12, 27 June 2012).

${ }^{14}$ According to the negotiating framework for Montenegro: 'should progress under [chapter 23] significantly lag behind progress in the negotiations overall, and after having exhausted all other available measures, the Commission will on its own initiative or on the request of one third of the Member States propose to withhold its recommendations to open and/or close other negotiating chapters, and adapt the associated preparatory work, as appropriate until this imbalance is addressed', Paragraph 25, General EU Position, Ministerial meeting opening the Intergovernmental conference on the accession of Montenegro to the European Union. 
and means to achieve their assimilation by the candidate. Both developments equally point towards a significantly strengthened EU monitoring, notably by the Commission, involving increased pressure through the possibility of corrective measures. In view of the worrying situation in some Member States, any initiative to ingrain EU values in future members' polity is commendable. Anticipatory measures to ascertain upstream assimilation of, and compliance with, fundamental rights might indeed contribute to them becoming a matter of course, and to reduce the risk of setback. Yet it remains doubtful that the new approach in itself is a guarantee of irreversibility.

\section{The Albania Case}

Actually, integration into the European Union has been a top priority stated in the programmes of all Albanian governments since the country gained its independence in 1991. This process for Albania started immediately after the fall of the totalitarian communist system (1991) and it has been a political and historical mission. On May 1992, Albania signed the Trade and Co-operation Agreement with the EC and in June 2006 the country completed in Luxemburg a long cycle of negotiations regarding the signature of the Stabilization and Association Agreement (SAA) with the European Union $^{15}$. Almost six years after the signature and the ratification of the SAA by all Member States, European Integration continues to be the paramount priority of the Republic of Albania.

Even more, the consensus on EU integration has been reached as the priority of all parliamentary political parties.It was consequently strengthened by the establishment of a joint task between the Government and the Parliament in the process of the EU accession. In 2005 the Parliamentary parties adopted several joint documents that ensure full cooperation between the two bodies in the process of the EU accession.

Applying the methodology presented in a vast literature on Europeanization that argues that the (pre-) accession process has direct impact on the improvement of the human right record of a candidate country, the paper proceeds in three parts.

The first part of this paragraph gives a chronological overview of the relationship EU-Albania and of the recent EU policies vis-à-vis Albania, particularly regarding the requirements the country was asked to fulfill. In the second part, the paper deals with actual human rights situation in the country during these years.

I. In 1991 we have the establishment of the diplomatic relations between Albania and EU.On 11 may 1992 there was signed an agreement called "Trade and Co-operation Agreement" between the EU and Albania, including the common declaration on the political dialogue which entered into force on 1 December 1992. The Trade and Cooperation Agreement, allowed Albania to benefit from PHARE program funds. This constitutes an important step towards restructuring EU assistance to Albania in a number of areas that corresponded to the reforms in which the country was involved. This agreement constitutes one of the most important contractual documents that Albania has signed in the past decade, which finally linked our country to the EU.In 1996we had a Regional Approach of Albania with EU.Also in this period, Albania is included in the General System of Preferences, which represented a general regime of trade preferences that EU offered to a large number of countries with which it had contractual relations. Albania was close to signing a new contractual agreement with the EU in 1996, which would paved the way for a classic association agreement. However, the contested parliamentary elections of May 1996, followed by the deep financial and social crisis at the beginning of 1997 after the fall of pyramid schemes, resulted in the failure of every initiative to this end. Political developments of this period in different regional countries, the dissolution of former Yugoslavia, the establishment of a number of new states, whose parameters were different from those of Central European countries, urged the European Union to adapt the called "Regional Approach" policy for Balkans countries ${ }^{16}$ The General Affairs Council at this time determined a number of political and economic conditions that Balkans countries should fulfill to develop and strengthen their EU relations. These criteria were linked to the respect of democratic services, human rights and liberties, the construction, respect and strengthening the rule of law, protection of minorities, development of market economy, and regional cooperation ${ }^{17}$. The EUCouncil of Ministers establishes political and economic conditionality for the development of bilateral relations. After the parliamentary elections of May 1996, Albania was facing the gravestfinancial and social

${ }^{15}$ On June 12 $12^{\text {th }}, 2006$ Albania signed the Stabilisation and Association Agreement (SAA) at the General Affairs and External Relations Council in Luxemburg and, on December, the Interim Agreement enters into force. In January 2009, the Procedures of ratification of the Stabilisation and Association Agreement between the Republic of Albania and European Union and its Member States are completed by all Member States. The documents are available at www.europa.euandwww.mie.gov.al. SeeThe Pre-AccessionDialogue EU-Albania, Tiranë, 2009, 8-86.

${ }^{16}$ Hoffman, J, (2005), Albanian Journal of Politics: The role of the European union in the democratization process, pg. 56.

${ }^{17} \mathrm{Kuko}, \mathrm{V}$, Stabilisation and Assocciation process in Albania and the Institutional Framework, European Journal of Integration, Albania, 2004, pg.1. 
crisis, which was flowed by the fall of the pyramidal schemes. The Council of the Common Issues, at that time, has appointed economic and political conditions for the candidates countries of the Balkans, such as:

1) respect of democratic principles,

2) fundamental human rights and freedoms,

3) establishment and enforcement of rule of law.

Albania has done a lot of efforts to join the "Club" of European Union but this country has to do more work concerning the fulfillment of the Copenhagen Criteria ${ }^{18}$. Albania received from the European Commission the candidate status in 24 June, and this will give a great hope to this country to implement the directives of the EU Commission. For this small country the integration at the European Union is the top priority of every government, because Albanian people in the majority of them agree that this should be the goal of Albania. They know very well that integration for them means better conditions in their life. During the two decades they haven't done the best things to bring Albania near European family and this has costs for the people leaving within Albania. This year and in the passing years we hope that relations between Albania-EU will be better andthis country will join European family as soon as possible.

II. Although it has achieved remarkable progress in its political, economic and social transformation, Albania still faces significant challenges and its democracy can be described as a 'work in progress.' Respect for human rights and the protection of minorities are enshrined in the Constitution and in a number of legislative provisions. Albania has ratified most human rights instruments; these are part of the internal judicial system and are directly applicable after publication in the Official Journal. Albania joined the Council of Europe in 1995, and ratified the European Convention on Human Rights in 1996. To date, the European Court of Human Rights (ECtHR) has delivered several judgments concerning Albania. The Court mainly found breaches of the right to a fair trial within a reasonable time, the right to an effective remedy and the right to peaceful enjoyment of possessions.

As the European Commission noted in its most recent annual progress reports, in the field of human rights, freedom of assembly and association, as well as freedom ofthought, conscience and religion, has generally been respected. In the field of antidiscrimination progress was made, for instance through the action plan on the rights of lesbian, gay, bisexual, transgender and intersex (LGBTI) persons. In the area of freedom of expression, the Law on Audio-Visual Media substantially improved the legislative framework for audio-visual media in Albania (2013).

According to the European Commission's Progress Report of 2013, in the field of human rights, the drafting of new legislation and implementation of existing legislation should be priorities, with a clear focus on the rights of persons with disabilities, children's rights and Roma inclusion. As concerns freedom of expression, additional efforts are required to fully guarantee the independence of the media regulatory authority.

Albania has taken some concrete steps to reinforce protection of human rights, and to effectively implement antidiscrimination policies - both areas are among the key priorities. It presents a mixed picture regarding human rights and the protection of minorities. Freedom of assembly and association, and freedom of thought, conscience and religion has generally been respected. Regarding freedom of expression, progress has been made. The Law on Audiovisual Media was adopted in March, substantially improving the legislative framework for audiovisual media in Albania. The law fails, though, to provide a selection procedure for the governing bodies of the regulator and the public broadcaster that guarantees their independence. Further steps are needed to fully decriminalise defamation. Interference in the media by political and economic interests needs to be limited. In the area of anti-discrimination policies, some legislation is in place - e.g. regarding the rights of lesbian, gay, bisexual, transgender and intersex (LGBTI) persons - and some is lacking, e.g. regarding the Roma community. The Albanian authorities need both to apply the existing legislation and to draft new legislation in the area of anti-discrimination. A number of concrete steps have been taken. An LGBTI action plan has been put in place, and the Criminal Code has been amended to take aggravating circumstances into account for offences relating to gender, race, ethnicity, gender identity, sexual orientation, political beliefs, religion, health status, genetic predisposition or disability.

In line with the national action plan on the Roma Decade, Albania needs to swiftly improve the living conditions of the Roma; coordination between central and local government is essential in this context. Another key area to focus on immediately is access to education and the inclusion of Roma children in the educational system - from pre-school level to higher education.

Public awareness of the Law on Protection from Discrimination and of the complaint mechanism remains low. The implementation of the law needs to be enhanced; victims of discrimination need to be encouraged to file complaints in order to establish solid case law. The roles of the offices of the Ombudsman and of the Anti-Discrimination Commissioner need to be clarified to render them more effective. The legal framework for economic and social rights has been

${ }^{18 D . S i n a, ~ V a s j a r i ~ A ., ~ C a n a j ~ E ., ~ A l b a n i a ' s I n t e g r a t i o n ~ i n ~ E U, ~ M J S S, ~ 2013, ~ p p .305-313 . ~}$ 
improved, but implementation is slow, particularly regarding people with disabilities and children at risk of abuse. Major and systematic efforts are needed to address persisting problems in the area of property rights.

Property restitution, compensation and illegal construction are issues that need to be tackled.

Albania needs to adopt and communicate a credible plan for the enforcement of European Court of Human Rights judgments on property rights. Labour and trade union rights have generally been respected.

\section{Conclusions}

The evolving pre-accession fundamental rights discourse might catalyze further internal adjustments to enhance the domestic EU fundamental rights regime. Enlargement and fundamental rights protection are thus significantly influencing one another: while the former contributes to enhancing the latter both externally and - by necessity - internally, enhanced domestic fundamental rights protection might in turn benefit enlargement and the Union's legitimacy more generally.

The present paper has primarily attempted to point towards the areas in human rights agenda that still require improvement in Albania, without presenting basic legislative provisions that assure human rights and a basis of current political situation in the country, assuming those aspects are for the most part familiar to the readership. A number of above enumerated improvements in the filed of human rights protection and promotion witness that the Albanian authorities have seized a path of democratic consolidation. The process of European integration that started in 1992 has played a crucial role in convincing politicians to alter their nationalistic attitudes and embracing pro-Western, democratic standards.

In Albania TheStabilisation and Association Agreement (SAA) continued to be overall smoothly implemented and Albania continued aligning its legislation to the requirements of the EU legislation in a number of areas, enhancing its ability to take on the obligations of membership.

Nevertheless, there are still areas in which human rights of Albanian citizens could be better dealt with.

Each year, the report, inter alia, analyses the situation in the country in respect of the political criteria for membership, i.e. the human rights and protection and promotion of the rights of minorities. In this way the Albanian authorities are constantly being aware that the respect for human rights constitutes an important pre-accession component, thus the European Union serves as a human rights watchdog.

\section{References}

Alston, Philip and JHH Weiler, "An 'Even Closer Union' in Need of a Human Rights Policy: The European Union and Human Rights", in Alston, Philip (Ed.). The EU and Human Rights. Oxford: Oxford University Press, 1999, pp. 3-66.

Balaj, B, \&Bugajski, J , , (2010), Western Balkans Policy Review 2010, pg. 49.

Bitzenis, A. (2009), The Balkans: Foreign Direct Investment and Eu Accession, pg. 127

Bogdani, M.\&Loughlin, John, (2007) Albania and the European Union: the tumultuous journey towards. pg. 215.

Christophe Hillion Enlarging the European Union and deepening its fundamental rights protection, European Policy Analysis 2013:11 . Page 1-4.

Communication from the Commission to the European Parliament and the Council, Enlargement Strategy and Main Challenges 2011-2012, COM(2011) 666 final, 12.10.2011, p. 5.

D.Sina, Vasjari A., Canaj E., Albania'sIntegration in EU, MJSS, 2013, pp.305-313.

de Witte, Bruno and Gabriel von Toggenburg, "Human Rights and Membership of the European Union", in Peers, Steve and Angela Ward. The EU Charter of Fundamental Rights: Law Context and Policy. Oxford: Hart Publishing, 2004.

Eeckhout, Piet. External Relations of the European Union. Legal and Constitutional Foundations, Oxford: Oxford University Press, 2004

Elsie, R. (2010), Historical Dictionary of Albania, pg. 130.

G. de Búrca, 'Beyond the Charter: How enlargement has enlarged the human rights policy of the EU' Fordham International Law Journal 27 , 2004, p. 679.

General EU position - ministerial meeting opening the Intergovernmental Conference on the Accession of Montenegro to the European Union (AD 23/12, 27 June 2012)

Hoffman, J, (2005), Albanian Journal of Politics: The role of the European union in the democratization process, pg. 56.

Inotai, A. (2007), The European Union and Southeastern Europe: troubled waters ahead, pg. 341.

Kochenov, Dimitry. "Behind the Copenhagen façade. The meaning and structure of the Copenhagen political criterion of democracy and the rule of law", European Integration online Papers (EloP), Vol. 8 No. 10, (2004).

Kuko, V, (2004), Stabilisation and Assocciation process in Albania and the Institutional Framework, European Journal of Integration, Albania,pg.1.

Löberbauer, H. (2006), The regional, structural and cohesion policy of the European Union: CARDS in Albania, pg. 2...

M. Cremona (ed), The Enlargement of the European Union, Oxford: Oxford University Press, 2003, pp. 9- 43.

Presidency Conclusions, European Council, Brussels, 15 December 2006.

Richard C. Frucht, (2004), Eastern Europe: An Introduction to the People, Lands, and Culture, pg. 726.

Sajdik, M\&, Schwarzinger, M . (2008), European Union Enlargement, Journal. (2003), Central and South-Eastern Europe 2004, pg. 323.

Tatham, Allan F. (2009) Enlargement of the European Union, pg. 167.

WilliamsA., 'Enlargement of the Union and human rights conditionality: a policy of distinction?',European Law Review 25, 2000, p. 601. 